\title{
Application of Emergency On Building Fire Using Ant Colony Optimization Method Based On Android
}

\author{
Khusaeri Andesa ${ }^{1}$, Herwin $^{2}$ \\ 1,2Program Studi Manajemen Informatika, STMIK Amik Riau, \\ Jl.Purwodadi Km.10 Panam Pekanbaru
}

\begin{tabular}{l} 
Article Info \\
\hline Article history: \\
Received 110 \\
Revised 1210 \\
Accepted 12 \\
\hline Keywords: \\
Ant Colony \\
Optimization \\
Fire \\
firefighter \\
Android
\end{tabular}

\begin{abstract}
Fire and Rescue Service is an agency to handles fire problems, i.e building fires. Fire and Rescue Service of Pekanbaru is an agency to handles fire problems in Pekanbaru where the service receives information about a fire incident quickly and responsively. Fire incidents can occur anywhere, in any location, both easy or difficult access, but the Firfighter Team must be prepared in every conditions. The problem is that not all fire incidents occur in easy access places by firefighters. The incidents sometimes occur in difficult places to reach and unknown location, firefighter have to use maps to find the location. It will be wasting time to find unknown location and took a long time to arrive. The solution of this problem is to build an android-based application that can be used as a fire incident report, which is connected in one application, so residents can report through an application automatically provides the coordinates of incident. The application of Ant Colony Optimization method in finding fire locations makes it easier to hasten in searching fire locations and can be used by the public in reporting fires to Fire and Rescue Service of Pekanbaru to be processed quickly.
\end{abstract}

This is an open access article under the CC BY-SA license.

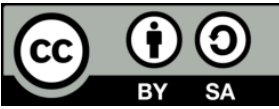

\section{Corresponding Author:}

Khusaeri Andesa

Program Studi Manajemen Informatika

STMIK Amik Riau,

Jl.Purwodadi Km.10 Panam Pekanbaru

Email: khusaeri@sar.ac.id

(C) Khusaeri Andesa dan Herwin 2021

\section{Introduction}

Fire and Rescue Service is an agency to handles fire problems, i.e building fires. Fire and Rescue Service of Pekanbaru is an agency to handles fire problems in Pekanbaru where the service receives information and handles fire incidents quickly and responsively.

Fire incidents can occur anywhere, in any location, both easy or difficult access, but the Firfighter Team must be prepared in every conditions. The problem is that not all fire incidents occur in easy access places by firefighters. The incidents sometimes occur in difficult places to reach and unknown location, firefighter have to use maps to find the location. It will be wasting time to find unknown location and took a long time to arrive. From the results of an interview with one of the firefighter, every month there were 2 (two) to 3 (three) fire incidents in Pekanbaru.

Based on research conducted by Euis Nurlaelasari, the search for optimal values can be used to obtain the highest and lowest values of the problem and the application can search for the route. Retnoningsih produce an Emergency Phone application with features of convenience and flexibility, run in Hybrid conditions online and offline providing excellent performance. optimally in displaying the nearest instance of the user's position 
[1], from Diana Fallo's research, that the results of the shortest path using ACO found the total travel time was faster. ACO works well in finding the shortest route because ACO does not depend on the given iteration [2], research by Via Risqiyanti et al., resulted in an analysis conducted by searching for the shortest path and the fastest path obtained the same results, namely the shortest distance of 114.62 kilometers with the fastest time of 232 minutes [3] . Therefore, from this research, it will build an android-based mobile application to provide related information about fire incidents and fire locations. Where this application helps officers or firefighters in overcoming building fires.

\section{Research Methodology}

\subsection{Literature Review}

2.1.1. Application

Application is software created by computer company to do certain tasks, for example Ms. World, Ms.Excel. Usually compared to system software integrates various computer capabilities, but it does not directly apply these capabilities to perform the task that profitable the user.

\subsubsection{Fire}

When a fire occurs, fire arises as a chain reaction between combustible materials (fuel), oxygen (O2), and heat which is often called fire triangle [5]. Fire disasters in urban areas cannot be predicted occur and the causes of fire, it can be done is doing preparation and early warning. To secure a building and its environment against fire, it is necessary to implement the technical requirements in regulating and controlling the building, including in the permit process, implementation, utilization and maintenance of the building, checking the feasibility of the function and reliability of the building against fire hazards.

\subsubsection{Ant Colony Optimization}

Ant Colony Optimization or Ant algorithm was introduced by Moyson and Manderick. It widely developed by Marco Dorigo. Ant algorithm is bioinspired metaheuristic, has a special group in trying to match the behavioral characteristics of social insects, they are ant colonies [6]. The behavior of each actor in imitating the behavior of live ants and how they interact with each other in order to find food sources and bring them to their colony efficiently. During the walk, each ant releases pheromone, where the other ants are sensitive to pheromone thus giving hope to follow its footsteps. More or less intensity depends on the concentration of pheromone. Pheromones are chemical compounds possessed by insects, especially ants, which are left in the ant's trail. After a few time, the shortest path will be followed more often and the pheromone will be colony. To simplify the system design process, analysis is needed before carrying out the next process. The analysis carried out is inputting the departure point, the nodes created at the crossroads and the distance between the nodes.

In the ant algorithm, several variables and steps are needed to determine the shortest path [7], namely:

\section{Step 1}

a. Initialize the value of the algorithm parameters.

The initialized parameters are:

1. Intensity of ant trails between cities and the changes $\left(\tau_{\mathrm{ij}}\right)$

2. Many cities (n) includes $x$ and $y$ (coordinates) atau $d_{i j}$ (distance between cities)

3. Determination of origin city and destination city

4. Ant-cycle constant (Q)

5. Ant trace intensity control setting $(\alpha)$

6. Visibility control setting $(\beta)$

7. Visibility between cities $=1 / \mathrm{d}_{\mathrm{ij}}\left(\eta_{\mathrm{ij}}\right)$

8. Number of ants (m)

9. Ant trace evaporation constant $(\rho)$

10. Maximum number of cycles $\left(\mathrm{NC}_{\max }\right)$ is fixed as long as the algorithm is run, while $\square_{\mathrm{ij}}$ will always be updated in every cycle of the algorithm starting from the first cycle $(\mathrm{NC}=1)$ until the maximum number of cycles is reached $\left(\mathrm{NC}=\mathrm{NC}_{\max }\right)$ or until convergence occurs.

b. Initialize the first city of each ant. After the initialization of $\tau_{\mathrm{ij}}$ is done, then $\mathrm{m}$ ants are placed in the first specified city.

\section{Step 2}


Filling the first city into taboo list. The result of initializing the first city of ants in step 1 must be entered as the first element of tabu list. The result of this step is the filling of the first element of tabu list of each ant with the index of the first city.

\section{Step 3}

The arrangement of the route of each ant's visit to each city. Ant colonies have been distributed to the first city will start traveling from the first city as the origin city and one of the other cities as the destination city. Then from the second city, each ant colony will continue its journey by choosing one of the cities that are not in $t a b u_{k}$ as the next destination city. The journey of the ant colony continues until it reaches predetermined city. If $s$ represents the index of the order of visits, the city of origin is expressed as $\operatorname{tabu}_{k}(s)$ and the other cities are expressed as $\left\{N-t a b u_{k}\right\}$, then to determine the destination city, the probability equation for the visited city is used as follows,

$$
\begin{gathered}
P_{i j}^{k}=\frac{\left[\tau_{i j}\right]^{\alpha}\left[\eta_{i j}\right]^{\beta}}{\sum\left[\tau_{i k}\right]^{\propto}\left[\eta_{i k}\right]^{\beta}} \text { untuk } j \in\left\{N-t a b u_{k}\right\} \\
\mathrm{k}^{\prime} \in\left\{\mathrm{N}-\mathrm{tabu}_{\mathrm{k}}\right\} \\
\mathrm{p}^{\mathrm{k}}=0 \text {, for another } \mathrm{j} \text { with } \mathrm{i} \text { as origin city index and } \mathrm{j} \text { as destination city index. }
\end{gathered}
$$

\section{Step 4}

a. Calculation of the length tour of each ant. Calculation of length closed tour or $\mathrm{L}_{\mathrm{k}}$ for each ant is carried out after one cycle is completed by all ants. Calculations are carried out based on each $t a b u_{k}$ with the following equation:

$$
L_{k}=d_{\text {tabu } u_{k}(n), t a b u_{k}(1)}+\quad d_{t a b u_{k}(s), t a b u_{k}(s+1)}
$$

where $d_{i j}$ is the distance between city $i$ to city $j$ which is calculated based on the equation:

$$
\mathrm{d}_{\mathrm{ij}}=\sqrt{\left(x_{i}-x_{j}\right)^{2}+\left(y_{i}-y_{j}\right)^{2}}
$$

b. Shortest route search. After $\mathrm{L}_{\mathrm{k}}$ for each ant is calculated, the minimum value for the length closed tour for each cycle or $\mathrm{L}_{\operatorname{minNC}}$ will be obtained and the minimum value for the length closed tour as a whole will be or $\mathrm{L}_{\min }$.

c. Calculation of price changes in the intensity of ant footprints between cities. Ant colony will leave footprints on the inter-city trajectory in its path. The existence of evaporation and the difference in the number of ants pass, causes the possibility of changes in the price of the intensity of ant footprints between cities. The equation of change is:

$$
\Delta \tau \mathrm{ij}=\sum_{k=1}^{m} \Delta \tau_{i j}^{k}
$$

Where $\Delta \tau_{i j}^{k}$ is the change in pheromone intensity value between point $\mathrm{i}$ and point $\mathrm{j}$ for ant $\mathrm{k}$ which will be calculated as follows:

$$
\Delta \tau_{i j}^{k}=\frac{Q}{C^{k}}
$$

Where for (ij) is the starting point and the destination point. With a predetermined value of $\mathrm{Q}$ is 1 , and $\mathrm{C}^{\mathrm{k}}$ is the sum of the total distance.

\section{Step 5}

a. Calculation of the intensity of ant footprints between cities for the next cycle. The price of the intensity of ant footprints between cities on all inter-city trajectories is possible to change due to evaporation and differences in the number of ants that pass through. For the next cycle, the ants that will pass the trajectory have changed the intensity value. The value of the intensity of ant footprints between cities for the next cycle is calculated by the equation:

$$
\tau_{\mathrm{ij}}=\rho \cdot \tau_{\mathrm{ij}}+\Delta \tau_{\mathrm{ij}}
$$


b. Reset the price of change in the intensity of ant footprints between cities. For the next cycle, changes in the intensity of ant trail intensity between cities need to be rearranged to have same value with zero.

\section{Step 6}

Empty taboo list, and repeat step two if needed. Taboo list needs to be emptied to be filled again with new order of cities in the next cycle, if the maximum number of cycles has not been reached or there has not been convergence. The algorithm is repeated from step two with the updated value of the intercity ant footprint intensity parameter.

\subsubsection{Android}

Android is an Open Source operating system can provide freedom for developers to develop an application. Another definition of Android is a Linux-based mobile device operating system includes an operating system, middleware and applications. Android provides an open platform for developers to create their own applications usage by various mobile devices.

On November 5, 2007, Android was first released. Along with the formation of OHA, OHA announced their first Android product, a mobile device which is a modification of Linux 2.6 kernel. At this time many vendors are using their Android Smartphone operating system. Such as HTC, Motorola, Samsung, LG, HKC, Huawei, Archos, Webstation Camangi, Dell, Nexus, SciPhone, Wayteq, Sony Ericsson, Acer, Asus and many other vendors.

\subsection{Research Methodology}

\subsubsection{Research Step}

Research step is the levels, it also called levels in a research activity. Where these steps have process conducted in a structured, coherent, standard, logical and systematic. At the research step using the following methodology:

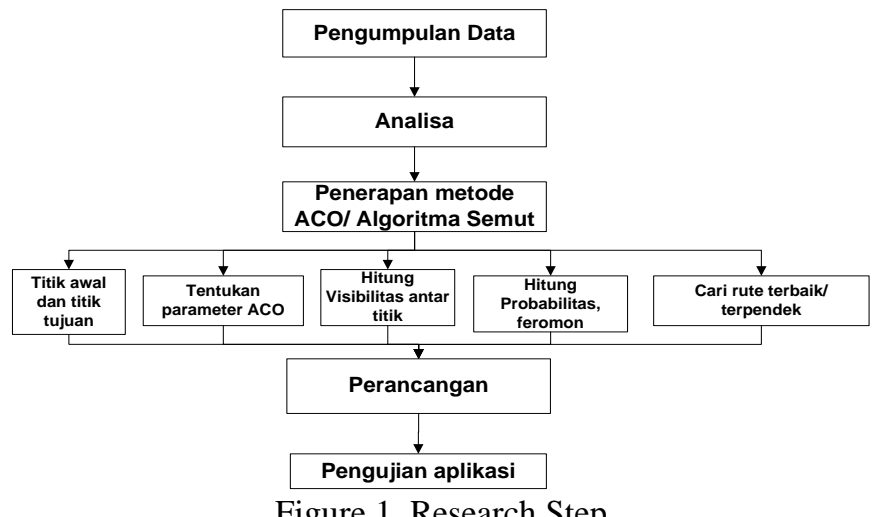

\subsubsection{Application of ACO Method}

The ACO algorithm or the ant algorithm will be placed on the application by the user to find the optimal distance from the position of the extinguisher and the location of the fire incident. The steps in solving the ACO algorithm or the ant algorithm to get the shortest route in the case of this fire service are:

1. Determining the node with the distance, it taken from in meters.

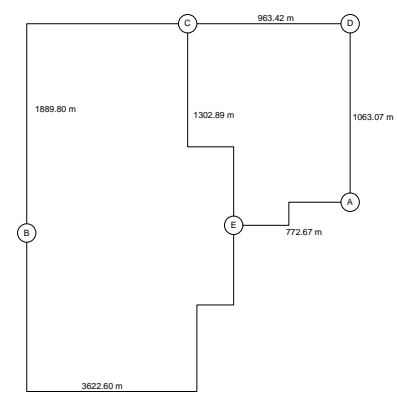

Figure 2. Nodes based on Map

Information : 
A,B,C,D,E = node/s

Node connecting line $=$ distance line between node 1 and others

Suppose the distance between the points (dij) is as follows:

Table 1. Distance between points (dij)

\begin{tabular}{cccccc}
\hline Node & A & B & C & D & E \\
\hline A & 0 & 0 & 0 & 1058,51 & 772,67 \\
B & 0 & 0 & 1886,39 & 0 & 3622,60 \\
C & 0 & 1886,39 & 0 & 960,42 & 1302,89 \\
D & 1058,51 & 0 & 960,42 & 0 & 0 \\
E & 772,67 & 3622,60 & 1302,89 & 0 & 0 \\
\hline
\end{tabular}

The parameters used are:

$\alpha=1$, ant trail intensity control constant

$\beta=1$, visibility control setting

$\rho=0.5$, The pheromone trace evaporation constant

$\mathrm{Q}=1$, the ant cycle constant

$\mathrm{m}=4$, Number of Ants

$\tau_{\mathrm{ij}}=0,021$, Initial pheromone

NcMax $=1$, maximum number of cycles

2. Determining the Initial Pheromone Value

Table 2. Initial Pheromone

\begin{tabular}{cccccc}
\hline Node & A & B & C & D & E \\
\hline A & 0 & 0,021 & 0,021 & 0,021 & 0,021 \\
B & 0,021 & 0 & 0,021 & 0,021 & 0,021 \\
C & 0,021 & 0,021 & 0 & 0,021 & 0,021 \\
D & 0,021 & 0,021 & 0,021 & 0 & 0,021 \\
E & 0,021 & 0,021 & 0,021 & 0,021 & 0 \\
\hline
\end{tabular}

3. Counting the visibility obtained

$$
n_{i j}=\frac{1}{d_{i j}}
$$

Table 3. Visibility

\begin{tabular}{cccccc}
\hline City & A & B & C & D & E \\
\hline A & 0 & 0 & 0 & 0,00094 & 0,00129 \\
B & 0 & 0 & 0,00053 & 0 & 0,00028 \\
C & 0 & 0,00053 & 0 & 0,00104 & 0,00077 \\
D & 0,00094 & 0 & 0,0010 & 0 & 0 \\
E & 0,00129 & 0,00028 & 0,00077 & 0 & 0 \\
\hline
\end{tabular}

4. Initializing the initial Ant for each node

Four ants (m ) start their journey from A point, will go to B point

Table 4. Ant Initialization

\begin{tabular}{cllll}
\hline Ant & 1 & 2 & 3 & 4 \\
\hline Initial Node & A & A & A & A \\
\hline
\end{tabular}


1. Arrangement of the route of each ant's visit to each city. Ant colonies have been distributed to the first city will start traveling from the first city as the origin city and one of the other cities as the destination city. Then from the second city, each ant colony will continue its journey by choosing one of the cities that are not in taboo $\mathrm{k}$ as the next destination city. The journey of ant colony continues until it reaches predetermined city. If s represents the index of the order of visits, the city of origin is expressed as $\mathrm{k}$ taboo (s) and other cities are expressed as $\{\mathrm{N}-\mathrm{tabu} \mathrm{k}\}$, then to determine the destination city, the probability equation for the city to be visited is used as follows:

$$
P_{i j}^{k}=\frac{\left[\tau_{i j}\right]^{\alpha}\left[\eta_{i j}\right]^{\beta}}{\sum\left[\tau_{i k}\right]^{\alpha}\left[\eta_{i k}\right]^{\beta}} \text { untukj } \epsilon\left\{N-\text { tabu }_{k}\right\}
$$

e.g. from A (start) to B (end/destination):

There are 4 possible paths/tour to take, namely: A-D-C-B, A-E-C-B, A-E-B and A-D-C-E-B.

Total distance of each ant:

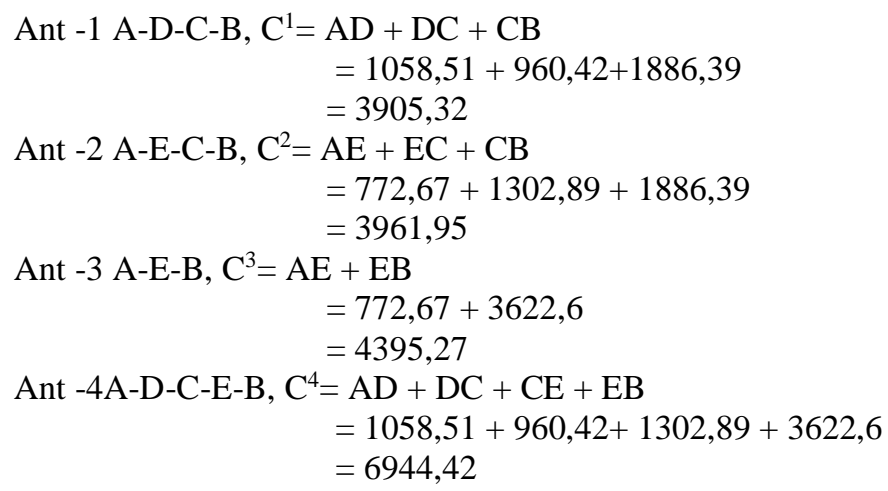

Calculate Ant Probability:

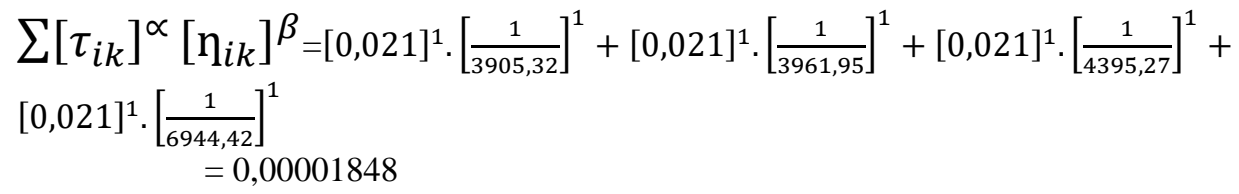

Ant Probability -1, A-D-C-B:

Ant Probability -2, A-E-C-B:

$$
\begin{aligned}
& =\left(0,021^{\wedge} 1 * 1 / 3905,32^{\wedge} 1\right) / 0,00001848 \\
& =0,2910
\end{aligned}
$$

Ant Probability -3, A-E-B

$$
\begin{aligned}
& =\left(0,021^{\wedge} 1 * 1 / 3961,95^{\wedge} 1\right) / 0,00001848 \\
& =0,2868
\end{aligned}
$$

$$
\begin{aligned}
& =\left(0,021^{\wedge} 1 * 1 / 4395,27^{\wedge} 1\right) / 0,00001848 \\
& =0,2585
\end{aligned}
$$

Ant Probability -4, A-D-C-E-B:

$$
\begin{aligned}
& =\left(0,021^{\wedge} 1 * 1 / 6944,42^{\wedge} 1\right) / 0,00001848 \\
& =0,1636
\end{aligned}
$$

2. Price change Pheromone intensity

To find the value $\Delta \tau \mathrm{ij}$, using the following formula:

$$
\Delta \mathrm{ij}=\sum_{k=1}^{m} \Delta \tau_{i j}^{k}
$$

Where $\Delta \tau_{i j}^{k}$ is the change in the pheromone intensity value between point $\mathrm{i}$ and point $\mathrm{j}$ for ant $\mathrm{k}$ which will be calculated as follows:

$$
\Delta \tau_{i j}^{k}=\frac{Q}{C^{k}}
$$


Where for (ij) is the starting point and the destination point

With the predetermined $Q$ value is 1 , and $C^{k}$ is the sum of the total distances previously calculated, it can be calculated as follows:

Ant pheromone change $-1=1 / 3905,32$

$$
=0,0002561
$$

Ant pheromone change $-2=1 / 3961,95$

$$
=0,0002524
$$

Ant pheromone change $-3=1 / 4395,27$

$$
=0,0002275
$$

Ant pheromone change $-4=1 / 6944,42$

\begin{tabular}{|c|c|c|c|c|c|}
\hline & Rute A - B & Total distance & Probability & & pheromone changes \\
\hline ANT 1 & $\mathrm{ADCB}$ & 3905,32 & & 0,2910 & 0,0002561 \\
\hline ANT 2 & AECB & 3961,95 & & 0,2868 & 0,0002524 \\
\hline ANT 3 & AEB & 4395,27 & & 0,2585 & 0,0002275 \\
\hline \multirow[t]{2}{*}{ ANT 4} & ADCEB & 6944,42 & & 0,1636 & 0,0001440 \\
\hline & & & $\Delta \tau \mathrm{ij}:$ & & 0,000880 \\
\hline
\end{tabular}

$$
=0,0001440
$$

Table 5. Probability, total distance and pheromone changes

The closest route A to B is ant route $-1, A-D-C-B$ because it has a high probability value, the shortest distance and the highest pheromone

2.2.4. System Implementation

a. Use Case Diagrams

There are actors who can access use cases in the system, including users, admins and firefighters.

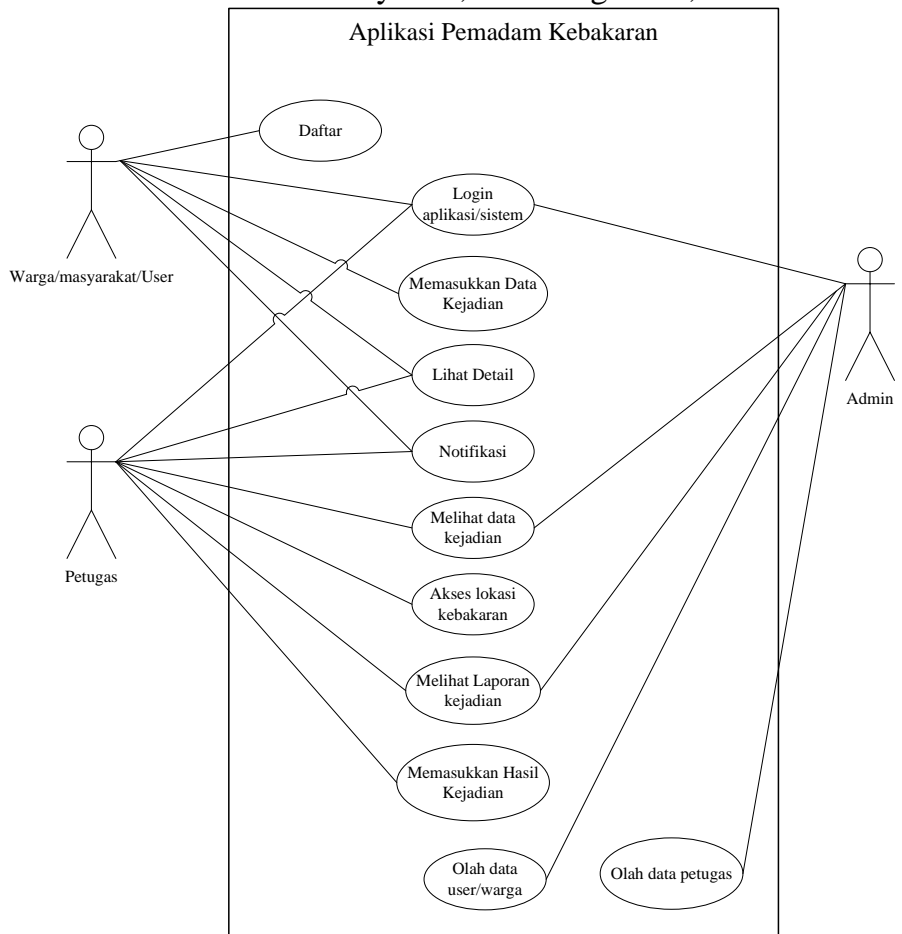

Figure 3. Use Case Diagram

Table 6. Use Case Diagram 


\begin{tabular}{|c|c|c|}
\hline Actor & Process & Keterangan Information \\
\hline User/Citizen & Register & $\begin{array}{l}\text { Before users/citizens use the application, they must first register } \\
\text { on the list menu first }\end{array}$ \\
\hline $\begin{array}{l}\text { Admin, Firefighter } \\
\text { and User/Citizen }\end{array}$ & Login & $\begin{array}{l}\text { Before using this application, admins and firefighter, users must } \\
\text { input their username and password and then log in first }\end{array}$ \\
\hline User/Citizen & Input Data & $\begin{array}{l}\text { Users/citizens have the right to input or complain about fire } \\
\text { incidents }\end{array}$ \\
\hline $\begin{array}{l}\text { User/Citizen, } \\
\text { Firefighter }\end{array}$ & See detail & Users/Citizens, firefighter can see in detail the fire incident \\
\hline $\begin{array}{l}\text { User/Citizen, } \\
\text { Firefighter }\end{array}$ & Notification & $\begin{array}{l}\text { Users/Citizens, firefighter can receive notification messages } \\
\text { from the fire incident }\end{array}$ \\
\hline Firefighter & Fire Location Access & $\begin{array}{l}\text { The officer after receiving the fire incident, will go to the fire } \\
\text { location which has previously been checked for the truth of the } \\
\text { fire }\end{array}$ \\
\hline Firefighter, Admin & See Incident Report & $\begin{array}{l}\text { Petugasmelihatlaporankejadiankebakarantersebut dan admin } \\
\text { dapat dan juga dapatolah data ataumelihatsecara detail } \\
\text { darilaporan-laporankejadiankebakarantersebut } \\
\text { The firefighter sees the report of the fire incident and the admin } \\
\text { can process the data or see in detail the reports of the fire } \\
\text { incident. }\end{array}$ \\
\hline Firefighter & Entering Incident Results & $\begin{array}{l}\text { After taking the action, the firefighter enters the results of the } \\
\text { incident related to fire data in the form of the number of dead, } \\
\text { the number of injuries, losses, and information. }\end{array}$ \\
\hline Admin & $\begin{array}{l}\text { User/Citizen Data Processing } \\
\text { Firefighter Data Processing }\end{array}$ & $\begin{array}{l}\text { For admins, login through the website here, the admin is in } \\
\text { charge of processing user data and processing firefighter data }\end{array}$ \\
\hline
\end{tabular}

b. Class Diagram

Class Diagram describes the state or attributes of the system. Class Diagram in the application determines the fastest path/tour to the location of the fire, there are 4 (four) classes are interconnected, which can be seen in the following figure:

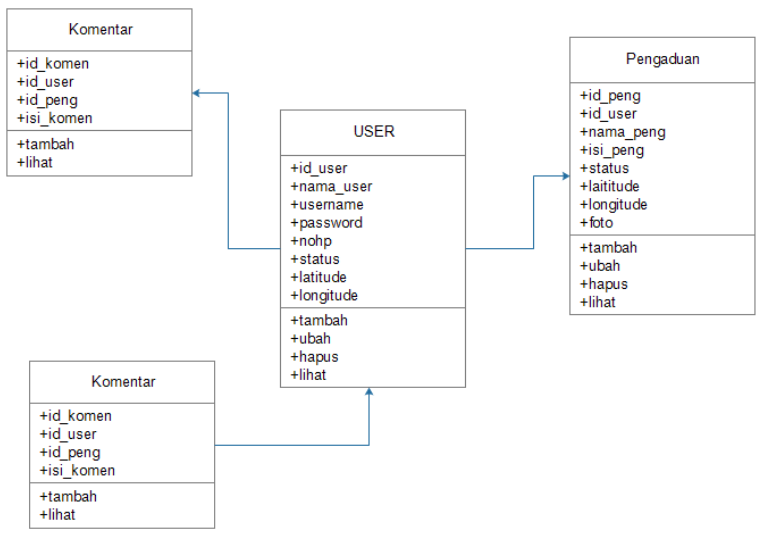

Figure 4. Class Diagram

\section{Result and Discussion}

\subsection{FormLogin}

In the login form, the firefighter before entering the application must enter login data after being registered by the admin on the application. 


\subsection{Main page}

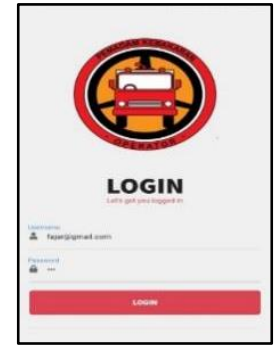

Figure 5. Login

On the main page, firefighter can view incident information reported by the public and can confirm and display notifications.

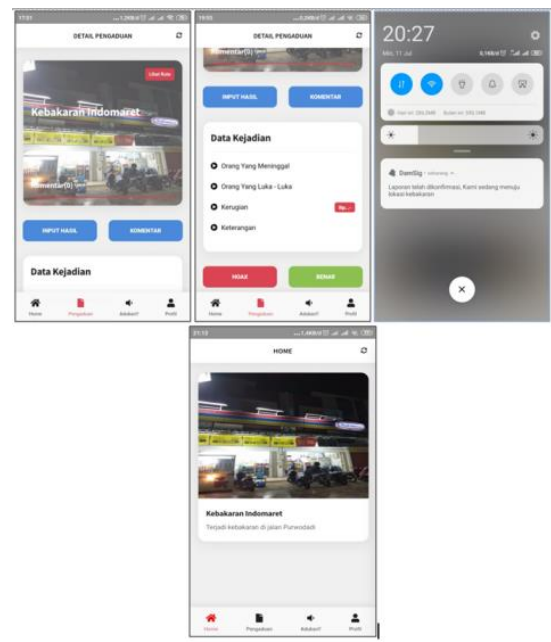

Figure 6. Main page

\subsection{Profile Display}

In the profile display, firefighter can view and change firefighter's personal data

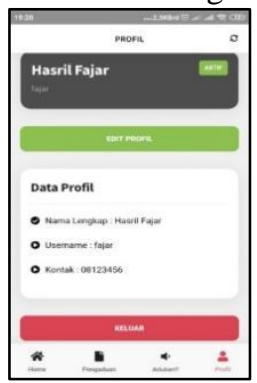

\subsection{Incident Result Input Display}

Figure 7. Profil

On the display, the firefighter inputs the results of the process such as the number of victims, losses and other information which is the display of incident data inputting incident data into the application.

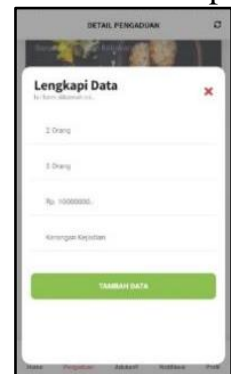

Figure 8. Incident Result Input Display 


\subsection{Location Search Display}

This map is to display the routes are passed according to the graph and nodes created. The static map display in applications where graphs and nodes are made independently and manually, used theoretically to calculate the closest distance of the node. The starting and ending positions have been determined by the node, if outside is not optimal in determining the closest distance and also the menu in the application does not work, so it cannot be done in the field, because the nodes and graphs have been created previously. So this static map only shows route choices are passed based on calculations

\section{Conclusion}

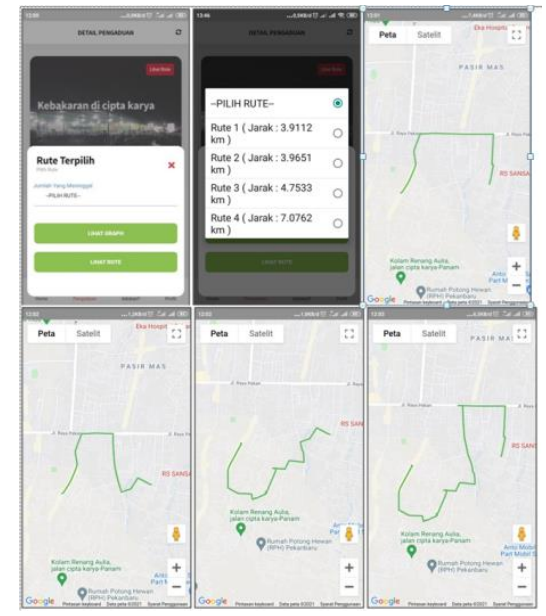

Figure 8. Location Search

After completing the steps for the development of fire fighting application using Ant Colony Optimization method based on android application, several conclusions can be drawn including the following:

1. In general, the system was built has been able to run and can produce data in accordance with the process of inputting fire incident reporting data.

2. The results of Ant Colony Optimization method in finding fire locations work well in the application.

\section{References}

[1] Retnoningsih, E. (2016). Aplikasi Informasi Telepon Darurat Menggunakan Android Berbasis Location Based Service (LBS). Jurnal Seminar Nasional Sains Dan Teknologi, 1(1), 1-9.

[2] Fallo, D. Y. (2018). Pencarian Jalur Terpendek Menggunakan Algoritma Ant Colony Optimization. Jurnal Pendidikan Teknologi Informasi (JUKANTI), 1(1), 28-32.

[3] Risqiyanti, V., Yasin, H., \& Santoso, R. (2019). Pencarian Jalur Terpendek Menggunakan Metode Algoritma "Ant Colony Optimization" Pada GUI Matlab (Studi Kasus: PT Distriversa Buana Mas cabang Purwokerto). Jurnal Gaussian, 8(2), 272-284.

[4] Maiyana, E. (2018). Pemanfaatan Android Dalam Perancangan Aplikasi Kumpulan Doa. Jurnal Sains Dan Informatika, 4(1), 54-65

[5] Setyadi, P. (2016). Karakteristik Penyebaran Api Ketika Terjadi Kebakaran Berbasis Metode FDS ( Fire Dynamics Simulator ) pada Parkiran Sepeda Motor Kampus A Universitas Negeri. Konversi Energi Dan Manufaktur UNJ.

[6] Karjono, Moedjiono, \& Kurniawan, D. (2016). Ant colony optimization. Intelligent Systems.

[7] I'ing Mutakhiroh. (2007). Pencarian Jalur Terpendek Menggunakan Algoritma Semut. Seminar Nasional Aplikasi Teknologi Informasi 2007 (SNATI 2007), 17 Juni 2007

[8] I'ing Mutakhiroh. (2007). Pencarian Jalur Terpendek Menggunakan Algoritma Semut. Seminar Nasional Aplikasi Teknologi Informasi 2007 (SNATI 2007), 17 Juni 2007

[9] Maiyana, E. (2018). Pemanfaatan Android Dalam Perancangan Aplikasi Kumpulan Doa. Jurnal Sains Dan Informatika, 4(1), 54-65. 